\title{
THE LEARNING MODEL OF O'BRIEN SHOT PUT FOR HIGH SCHOOL STUDENTS
}

\author{
Jupianto Sembiring*, Hernawan, Wahyuningtyas Puspitorini \\ Correspondence: Universitas Negeri Jakarta, Jakarta, Indonesia \\ E-mail: jupiantosembiring29@gmail.com
}

\begin{abstract}
The aim of this research was to produce and develop an O'Brien shot put learning model for high school students. This study used the Research and Development (R\&D) method from Borg and Gall, while the subjects in this research and development were students of SMAN 8 DEPOK. In limited trials (small group trials) using 20 students and large group trials using 60 students while the effectiveness test used 40 students. In the test of effectiveness of learning model used the instrument assessment of preparation phase, slip phase, delivery phase and recovery phase skills using a rubric / portfolio (process assessment). Data analysis in this study used the t-test, the results of the initial test before being given the treatment of the O'Brien shot put learning model was equal to 47.70 then after being given the treatment of O'Brien shot put learning model turned up to 83.68. In the significance test of the difference with the application of SPSS Statistics, the t-count result was $-85,377$ and Sig. (2-tailed) $0.00<0.05$ which means that there were significant differences in the O'Brien Shot Put learning model for high school students before and after the treatment of the O'Brien Shot Put learning model was given. Based on the analysis of the data above it was said that the O'Brien Shot Put learning model for high school students was effective and could improve the learning outcomes of the O'Brien Shot Put for high school students.
\end{abstract}

\section{Keywords: Learning, The O'brien of Shot Put}

\section{Introduction}

Physical education is one of the subjects taught to students ranging from elementary schools (SD), junior high schools (SMP), and senior high schools (SMA). Physical education shapes students to have a habit of exercising, so that it becomes a healthy lifestyle, and can correct wrong development and growth. For example, the wrong way to walk, the wrong attitude to sit, not confident and others, this can be addressed before it becomes a permanent habit in physical education learning. Physical education is a learning that must be taught to all students, because physical education material has a difference with other learning, in addition to learning the theory, students also have to practice directly physical activities or sports which are adjusted to the level and characteristics of students such as honesty, discipline, confidence and cooperation. Adi Prastyo Kurniawan (2016) states that "physical education, sports and health aim to help students develop physically, mentally, and socially. This is what distinguishes physical education, sports and health from other subjects ". 
Winarno \& Surendra (2016) Physical education is an integral part of the overall education system, aimed at developing aspects of health, physical fitness, skills, critical thinking, emotional stability, social skills, reasoning and moral action through physical activities and sports. National Education Standards Board, one of the objectives of the implementation of physical education, sports and health is to improve the ability and basic movement skills. The basic motion here refers to road, run, jump and throw, "Tomi \& Sudjana (2011). Physical education taught in schools is divided into several sports which consist of big ball sports, small ball sports, gymnastics, athletic sports and other sports. Learning sports in schools such as big ball sports and small ball sports that have an element of playing make students very enthusiastic about learning. This is the main capital or the most important main requirement in the teaching and learning process, with enthusiasm and pleasure in learning, the learning objectives will be easily achieved. However, unlike the case with the learning of shot put, students are less enthusiastic about learning, the learning objectives will be difficult to achieve due to lack of enthusiasm, causing students to become lazy in their activities. Improving the quality of education lies in the quality of teachers, therefore educational actors, especially teachers, are required to master and innovate both in the use of learning methods, as well as the facilities and infrastructure available for the achievement of improving the education quality. In addition, teachers are as innovators who have the responsibility to implement innovations in the administration of education in schools, Agustina (2013).

In this case, the teacher is required to make creativity, skills, ability to develop learning media so that students are not bored, therefore students are passionate and motivated to learn. Learning media must be further developed, do not just focus on one media that makes students bored, so that learning objectives are not met. Learning media development must indeed continue to be developed, so all students are enthusiastic in participating in learning and make students more creative activities. To achieve an education quality in practice the learning process must be able to meet all student needs or in other words the student-centered learning process. Besides, education must also be able to deliver each individual in order to survive, compete, independently in a dynamic life and move quickly full of competition, Adhen Willy Munendra 1 (2015).

Throwing is an athletic sport which consists of numbers: javelin, discus, hammer throw and shot put. Shot put is one of the throw sports which has another term with other throw sports, because its motion is shot not throw. Shot put is a form of movement to reject or push a round tool with a predetermined weight made of metal or called a bullet, with the aim of rejecting as far as far away. The O'brien shot put is the initial attitude of the body to turn towards repulsion. "The o'brien shot put is a technique which starts repulsion facing the back of the ring", Muh. Wajedi Efendi \& Dadang Warta Chandra (2016).

Shot put is an athletic learning which is generally taught in grade XI of High School (SMA). In general, this learning is less desirable by students. This is evident from the enthusiasm of students following the shot put learning, the lack of enthusiasm of students is caused by several factors. The first factor, the use of bullets which still use real bullets, makes students anxious and afraid to do so. The 
second factor is the delivery of less varied material and learning media which are too monotonous, which makes students bored and lazy to participate in learning. If students are bored and lazy to participate in learning, then the objective of physical education learning cannot be achieved and students will always assume that athletic learning is monotonous learning.

From the observations conducted when learning the material of shot put, students are less enthusiastic in participating learning material of shot put. This situation is a threat and a problem for physical education teachers, how to find solutions so that the learning of shot put is in demand by students. If the state of physical education learning continues like this, then physical education learning will most likely become learning that students dislike. Teaching students, who are passive and lazy in learning, will not be able to get an effective learning as desired. After making observations, this is due to the lack of creative learning models, media, monotonous. The solution that must be done is that the teacher must create learning media which is as attractive as possible for the learning of O'brien shot put.

Learning model is one way which can be carried out by a teacher involving students to learn more actively, creatively, and critically. Developing a learning model will automatically motivate students to continue to take part in the physical education learning. Because it gives students the opportunity to imagine implementing what they want to develop to their own friends, so that the hidden talent within them is channeled. Varied learning models, very promising students to be more active and think critically in learning. That is why the development of the learning model is very much needed for physical education learning, especially shot put, so that students are enthusiastic to participate in physical education learning. The teaching model is a teaching planning guideline in the form of a conceptual framework which describes the systematic procedure of the learning process to achieve the goals ", Adhen Willy Munendra (2015).

After the creation of a learning model conducted by the teacher, both from the delivery of material, modifying the tools, places and learning media. It is also hoped that it can create healthy students physically and mentally, and remind the importance of exercising to cultivate a healthy life. This is carried out to bring a positive impact on changes in the growth and development of students, positive thinking, creative and critical in thinking. In order to create a healthy young generation, so that it will provide good controversy to compete to be the best and bring positive changes to the progress of physical education learning.

The existence of the problem, in the background above, the authors conclude that it is very necessary to develop a learning model, which can motivate learning and have a positive impact that makes students active in learning. The learning model also makes it easy for physical education teachers to deliver learning material to students. So overcoming the problems above, it is really needed a solution on how to achieve physical education learning goals. Through learning models that are varied and interesting will make students continue to be active and critical in thinking so that learning objectives will be met.

This research focuses on the development of O'brien shot put learning model. After that the writer will try to correct the deficiencies in the learning 
process of physical education as well as find solutions and try especially physical education, athletic learning will make subjects enjoyable. So that students will not feel bored following the learning, and enrich the experience of movement and knowledge of students, which will make the results of this study one of the teaching materials to improve the teaching and learning process.

\section{Method}

The developed model concept is a development of learning media to improve the shot put skills of O'brien style through modification media with the target media being varied. The development of learning media is expected to be able to optimize the learning process of O'brien shot put which is more efficient and effective for Senior High Schools (SMA) whose ability is not yet skilled in doing o'brien shot put. The Borg and Gall development model is explained systematically and clearly as a reference for developing learning models. These are the following steps of the Borg and Gall (1983) learning model, namely:

1. Research and information collecting, in this step, among others, the study of literature relating to the problem being studied, measurement of needs, small-scale research, and preparation to formulate a research framework.

2. Planning, in this step compile a research plan which includes formulating skills and expertise related to the problem, determining the objectives to be achieved at each stage, design or research steps and if possible / necessary to carry out an appropriateness study on a limited basis.

3. Develop the preliminary form of product, which is to develop the initial form of the product to be produced. Included in this step are the preparation of supporting components, preparing guidelines and manuals, and evaluating the appropriateness of supporting tools. Examples,


instruments.

4. Preliminary field testing, which is conducting initial field trials on a limited scale, involving 1 school, with a total of 20-60 students. In this step data collection and analysis can be conducted by interview, observation or questionnaire.

5. Main product revision, which is to make improvements to the initial product produced based on the results of the initial trial. This improvement is very likely to be done more than once, in accordance with the results shown in limited trials, so that the main product (model) draft is ready for wider testing.

6. Main field testing, usually called the main trial involving a wider audience, namely 1 school, with a number of students from 20 to 60 people. Data collection is carried out quantitatively, mainly carried out on the performance before and after the implementation of the trial. The results obtained from this trial is in the form of an evaluation towards the achievement of trials result (design models) were compared with the 
control group. Thus in general this step uses an experimental research design.

7. Operational product revision, which is making improvements / perfections to the results of wider trials, so that the product developed is an operational model design that is ready to be validated.

8. Operational field testing, namely the validation test step related to the operational model that has been generated. It is implemented in 1 school involving 20 to 60 students. Testing is conducted through a questionnaire, interview, and observation and analysis of the results. The purpose of this step is to determine whether a model developed is truly ready for use in schools without having to be briefed or mentored by researchers / model developers.

9. Final product revision, which is to make final improvements to the model developed to produce the final product (final).

10. Dissemination and implementation, namely the step/of disseminating products / models developed to the public / the wider community, especially in the arena of education. The main step in this phase is to communicate and socialize findings / models, both in the form of research seminars, publications in journals, and exposure to stakeholders related to research findings.

As the statement of Ali Maksum (2012) states that "this trial aims to (1) to find out whether the design of the model has been implemented properly and correctly by the teacher, (2) how effective the results of applying the model to the objectives of this study", Ali Maksum (2012). Thus the quantitative approach is used to find the effectiveness of the pre-experimental research design in the form of the one group pretest-posttest design as follows:

\begin{tabular}{cccc}
\multicolumn{4}{c}{ Table 1. Research Design in Test } \\
Model Effectiveness \\
\hline Subjects & Pres-Test & treatment & Post-Test \\
& & & \\
\hline R & $\mathbf{0 1}$ & $\mathbf{P}$ & $\mathbf{0 2}$ \\
\hline
\end{tabular}

Steps undertaken in this trial include; (1) assigning groups of research subjects; (2) conducting a pre-test $(\mathrm{O} 1)$; (3) try a model that has been developed; (4) carrying out post-test $(\mathrm{O} 2)$; (5) looking for pre-test and post-test average scores and comparing them; (6) find the difference between the two averages through the statistical method (t-test) to find out whether there is a significant effect of using the Formula model to process the overall data of the test subjects using t-test procedures and using the SPSS application and to obtain the results of the pre-test and post-test, the researchers get the results of the skills data through the assessment of the o'brien shot put instrument. 
The O'brien Shot Put Skill Test used the process results of the shot put skills by referring to the assessment rubric with 4 indicators. 1. Preparedness. 2. Slide Shot Phase. 3. Delivery Phase. 4. Recovery Phase.

\section{Discussion}

After going through a small group trial and revising the second stage of the product development of o'brien shot put learning model, followed by field trials and the third stage revision of the product component development of o'brien shot put learning model, then to know the average effectiveness of the product, a process was carried out implementation with the effectiveness test data collection using the T test with SPSS software. Product trials were carried out by 40 students.

The average result of pre-test of o'brien shot put learning is 47.70. After being treated with 12 learning models of o'brien shot put, a post-test or final test is performed and the average post-test score was 83.68. Based on the description above, the results of the data after being calculated use the IBM SPSS Statistics application. The following results were displayed after calculating the Paired Sample Statistics, Paired Sample Correlations, and Paired Sample Test

From the explanation above, it was concluded that in general the results of summary descriptive statistics before being treated with the pre-test data learning model showed that 40 subjects obtained Mean 47.70, Std. Deviation 2,893 and Std. Error Mean 457. After being given product treatment the model developed by post-test data showed that 40 subjects obtained Mean 83.68 Std. Deviation 1,789 and Std. Error Mean 283. It meant the average value of o'brien shot put learning increased.

Tabel 2. Paired Samples Statistics

\begin{tabular}{ccccc}
\hline \multicolumn{2}{c}{$\begin{array}{c}\text { Journal Physicanducation, Health } \\
\text { Neviation }\end{array}$} & $\begin{array}{c}\text { Std. } \\
\text { Deved }\end{array}$ & $\begin{array}{c}\text { Std. Error } \\
\text { Mean }\end{array}$ \\
\hline Pair 1 PRE TEST & 47.70 & 40 & 2.893 & .457 \\
\hline POST TEST & 83.68 & 40 & 1.789 & .283 \\
\hline
\end{tabular}

Tabel 3. Paired Samples Correlations

\begin{tabular}{cccc}
\hline & N & Correlation & Sig. \\
\hline $\begin{array}{c}\text { Pair 1 PRE TEST \& } \\
\text { POST TEST }\end{array}$ & 40 & .432 & .005 \\
\hline
\end{tabular}

In the significance test of the difference with the application of SPSS Statistics, the t-count result was -85.377 and Sig. (2-tailed) $0.00<0.05$ which meant that there was a significant difference in the model of o'brien shot put learning for high school students before and after the treatment of o'brien shot put learning model was given. Based on this information it was concluded that, there 
was a significant and effective difference and could improve the learning outcomes of the o'brien shot put learning for high school students.

In the course of a study there were certainly supporting and inhibiting factors in its implementation. Of course this is also experienced by researchers, several supporting factors experienced during conducting research include:

1. Guidance and direction given by the supervisor in carrying out research were very helpful to researchers in completing the research model of the o'brien shot put learning.

2. In conducting the research process, researchers felt they have the full support of high school students as well as physical education teachers and lecturers in athletics courses.

3. The selection of appropriate experts and have free time to conduct discussions about variations in the model developed were very helpful in the process of conducting research

While the factors considered as obstacles in the development of this model were:

1. Because the learning model of o'brien shot put used a lot of tools to carry out the learning process and its implementation, the researcher used the tools and learning facilities that were modest.

2. To better provide a sense of security and comfort in learning, the use of bullets made of plastic balls filled with sand and used softball balls to replace the original bullets so that the field made of cement is not damaged.

3. Unpredictable weather factors such as rain sometimes became an obstacle to-outdoor learning al Education. Health and Recreation

\section{Conclusion}

Based on the data obtained, from the results of small group and large group trials as well as field trials and discussion of research results it was concluded that:

1. With this o'brien shot put learning model, students can apply and implement learning effectively and efficiently.

2. With the material of the o'brien shot put learning model that researchers have developed, students can understand the material in class well and carry out the practice skillfully.

\section{References}

Adhen Willy Munendra, R. L, 2015. Pengembangan Model Pembelajaran Lempar Lembing Untuk Siswa Sekolah Menengah Pertama (SMP). Keolahragaan, 3 (Model Pembelajaran), 127-138.

Adi Prastyo Kurniawan, S. C. Y. H, 2016. Penerapan Model Pembelajaran Dengan Pendekatan Bermain Terhadap Peningkatan Keterampilan Gerak Dasar Dalam Pembelajaran Pendidikan Jasmani , Olahraga Dan Kesehatan ( Studi Pada Siswa Putra Kelas Vii Smp Negeri 1 Balongpanggang Gresik ). 
Jurnal Pendidikan Olahraga Dan Kesehatan, 04, 148-156.

Agustina, E. T. (2013). Implementasi Model Pembelajaran Snowball Throwing Untuk Meningkatkan Hasil Belajar Siswa Dalam Membuat Produk Kria Kayu Dengan, $I x(1), 17-28$.

Ali Maksum, 2012. Metode Penelitian Dalam Olahraga. Surabaya: Unesa Univerity Press.

Borg. W.R \& Gall, M. D, 1983. Education Research An Introduction. New York: Longman.

Muh. Wajedi Efendi,Dadang Warta Chandra, A. S, 2016. Upayameningkatkan Hasil Belajar Tolak Peluru Gayao'brien Melaluimodifikasi Bola Plastik. Jurnal Pendidikan Olahraga Dan Kesehatan "Gelora," 3 (Meningkatkan Hasil Belajar), 421-427.

Tomi, I. P. A. A., \& Sudjana, I. N, 2011. Metode Bermain Dalam Pembelajaran Pendidikan Jasmani Siswa Kelas III C Sdn Krian 3 Kabupaten Sidoarjo. Pendidikan Jasmani.

Winarno, R. F. S. M. E., \& Surendra, M, 2016. Model Pembelajaran Teknik Dasar Tolak Peluru Gaya Menyamping Siswa Kelas VII Di SMPN 12 Malang. Jurnal Pendidikan Jasmani. Volume: 26, Edisi: 1: 176-186.

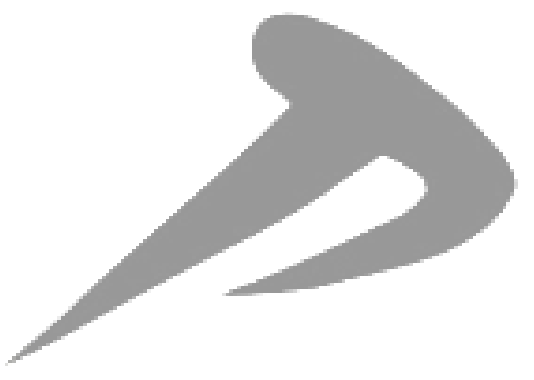

Journal Physical Education. Health and Recreation



